HRYNYUK Nataliya,

$\mathrm{PhD}$ (Economics), Associate Professor,

Kyiv National University of Trade and Economics

19, Kyoto str., Kyiv, 02156, Ukraine

E-mail:n.hrynyuk@knute.edu.ua

ORCID: https://orcid.org/0000-0002-4265-1421

\title{
COOPERATIVE CONSUMER NETWORK OF EUROPE
}

The tendencies of organizational development of the world cooperative movement have been investigated. The institutional preconditions of international cooperative cooperation are determined. The results of the activity of the European Community of Consumer Cooperatives are analyzed. The basic directions of activity of association of consumer cooperatives of Europe are proved.

Keywords: cooperation, consumer cooperation, European consumer cooperative network, EuroCoop.

Гринюк Н. Кооперативная потребительская сеть Европы. Исследованы тенденции организационного развития мирового кооперативного движения. Определены институциональные предпосылки международного кооперативного сотрудничества. Проанализировань результаты деятельности европейского сообщества потребительских кооперативов. Обоснованы основные направления деятельности объединения потребительских кооперативов Европы.

Ключевые слова: кооперация, потребительская кооперация, европейская кооперативная потребительская сеть, EuroCoop.

Background. During the last century, the world cooperative movement has undergone active development, which has been marked by the growth of the number of cooperatives and their members, the consolidation of cooperative organizations and the concentration of cooperative capital, an increase in the scale of economic activity of cooperatives, an increase in the influence of cooperative ideology, active cooperation of cooperatives on the national and international levels with the formation of an international cooperative network $[1 ; 2]$. Cooperative activities are an integral part of the modern economy of most countries: there are more than 1 million cooperative organizations in the world with more than 130 species that bring together more than 1 billion people [3].

The particular importance of the cooperative sector of the economy confirmed by the experience of developing the form mentioned above of management in EU countries: almost half of the total number of cooperatives in the world are European cooperatives, whose members are about 150 million people from 46 European countries [4]. The results of the study

(C) Hrynyuk N., 2020

ISSN 1727-9313. ВІСНИК КНТЕУ. 2020. № $2=69$ 
of trends in the development of the cooperative sector of the economy in Europe allowed us to formulate such characteristic features of this process: significant, continually increasing volumes of activity of cooperative enterprises and organizations; high level of competitiveness of cooperative enterprises on the national and world markets; active state support and encouragement of cooperative activity; diversification and industrialization of traditional types of cooperatives; the growth of the capacity of the tertiary sector cooperatives; high level of integration of cooperatives in different fields of activity; growth of the innovative nature of cooperative management; active support and mutual assistance of cooperative organizations of different countries among themselves; deepening of the international integration of cooperatives [5].

Cooperation of cooperative organizations today takes place on a global and continental scale. Cooperation penetrates all new spheres of human life, in particular in education, health care, sports, tourism.

The primary trend in the development of the modern cooperative movement is the intensification of international cooperation at the regional and world levels.

In the context of globalization of the economy and the information revolution, the economic expediency of activating the cooperation of cooperative organizations reflected in a more effective mechanism of resource support activities, production modernization, the introduction of new technologies, the exchange of experience and training of personnel. International cooperation within the framework of a single network is carried out now both based on special partnership agreements and through international cooperative organizations.

Analysis of recent researches and publications. The research of the activities of the modern international cooperative movement is devoted to the scientific works of many domestic and foreign scholars [6-9].

Vysin V., Vysina T., Kravchuk P. focus on the study of the current organizational structure and priority areas of activity of the International Cooperative Alliance (ICA) as the world centre of the cooperative movement [9]. Manzhura O., emphasizing the need to adapt the experience of the European cooperative movement to Ukrainian conditions, defines the creation of a national cooperative alliance as the main strategic direction for integrating the cooperative model of the national economy into the activities of the cooperative sector of Europe [8].

Western researchers of the cooperative movement Borzaga C., Michie J., Blasi R. have emphasized the importance of effective international collaboration to enhance the competitiveness of cooperative systems in different countries [6]. The focus of Cocolina $\mathrm{C}$. is the problem of adapting cooperatives to the global trends of globalization and internationalization [7].

Without diminishing the importance of their scientific developments, it should be noted that, in the majority of cases, the international cooperative movement considered from the standpoint of the institutional mechanisms 
of its development, and only a few works in a generalized form cover issues of the modern structure, forms and methods of activity of the international cooperative movement.

Besides, insufficient attention is paid to the study of the principles of governance and opportunities for regional cooperatives as a means of developing international economic activity.

In view of the above, the aim of the article is to investigate the strategic directions of the European Consumer Cooperative Community activities and the prospects of network development in the context of increased integration and globalization.

Materials and methods. The research methods used in the process of writing the article involve the application of general scientific and empirical techniques based on a systematic approach. The following methods of general theoretical and empirical research were used in the article: generalization, comparison, analysis and synthesis, formalization.

Results. Favourable institutional conditions for international cooperative cooperation and integration of the cooperative sector of different countries have been created in Europe today. Particularly active support for the activities of cooperative organizations is influenced by European economic institutions (European Commission, ICA Europe, Coordination Committee of the European Cooperative Association (CCACE), European Cooperative Projects Project) and supranational organizations, in particular UN specialized agencies (International Labour Organization (ILO), World Food and Agriculture Organization, Organization for Education, Culture and Science (UNESCO), Organization for Industrial Development (UNIDO), Capital Fund the Development (UNCDF).

The last decade for the European Union's cooperatives was marked by a concentration of efforts in three main areas: expanding the scope of cooperative associations, improving cooperative legislation, and recognizing the EU's political structures as cooperatives of the right place in realizing the tasks relevant to the European community [10].

The analysis of both the world and European experience of the cooperative sector of the economy proves the vital role of consumer cooperatives in economic development, especially during the transformation processes. It is in the part of consumer co-operation that the current international cooperative movement characterizes extremely positive trends: the growth of volumes of activity; the penetration of cooperation in new spheres of human life (recreation, education, health); revitalization of cooperative activity in the financial sphere, especially in terms of lending and insurance; increasing the number and increasing the role of multi-functional cooperatives and consumer societies in the cooperative sector of the economy; increasing the role of international cooperation at the regional and global levels.

The "oldest" organization in the European Cooperative Network is the European Consumer Cooperatives Association [4]. Founded in 1957 by the Cooperative Unions of the Common Market, the European Community of 
Consumer Cooperatives became one of the first non-governmental organizations recognized by the European Commission. For members of its association, EuroCoop offers tools for interacting with the European Union institutions (European Parliament, European Commission, Council of the European Union) to lobby for the interests of consumer co-operation in the European area.

Today the union of EuroCoop members is the strongest retail and retail association in Europe, with an annual turnover of around 80 billion euros. By combining 36 thousand sales outlets, 700 thousand workers in Europe, 7 thousand cooperative organizations at the local and regional level into a single trading network, the European cooperative consumer network serves 34 million consumers every day [11].

EuroCoop represents and supports the structure and functioning of European consumer cooperatives. First of all, as a result of close cooperation with the European Economic and Social Committees, the interests of European consumer co-operation are well represented in the decisions of the European Parliament. The activities of EuroCoop are implemented, in particular, by the organization's participation in various forums such as the EFSA Partner Platform, various advisory groups and platforms within the European Commission (EU Platform for Action on Food, Physical Activity and Health), European Retail Forum, European Consumer Consultative Group "ECCG", Consultative Group on the Food Network and Animal and Plant Health, and others. Besides, according to an agreement with the International Cooperative Alliance, EuroCoop provides support to the World Consumers' Cooperative Organization (CCW) [12].

Within its activities, at the head of the European Consumer Cooperation Network, EuroCoop realizes four main goals in the interests of consumers:

- promotion of economic and social goals of members of consumer cooperatives to European institutions;

- protection of a responsible and ethical approach to food, sustainable development of the European level of consumption;

- informing the members of the organization about European policies and initiatives related to their activities;

- providing a forum for the exchange of information and coordination of the general interests of members of the organization.

Also, the organizational goals of the association are to promote the objecttives of the International Cooperative Alliance and to support policies and initiatives at the national level aimed at developing national cooperative networks.

Summarizing the peculiarities of the activities of the European community of consumer cooperatives, in our opinion, the main directions of its activity should be considered: target, fundamental-organizational and strategic, which are reflected in the relevant policies (figure). EuroCoop's work is based on cooperative values and principles, contributing to the creation of a cooperative model as a means of creating a more democratic, responsible and just Europe. 


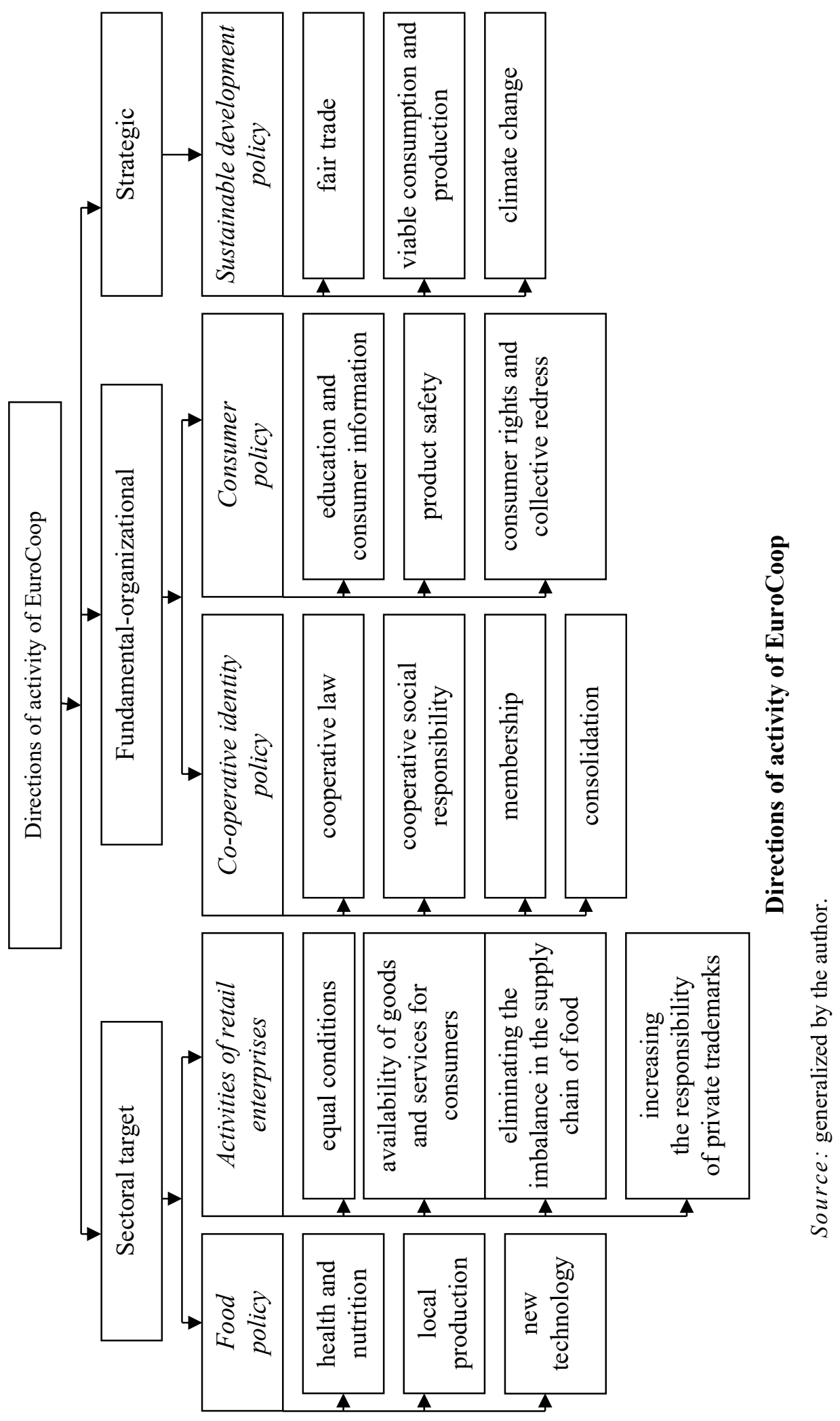

ISSN 1727-9313. ВІСНИК КНТЕУ. 2020. № 2 
The sector-specific direction of activity corresponds to the peculiarities of functioning of enterprises and organizations of the European network of consumer co-operation, which reflected in the food policy and activities of retail enterprises.

The food policy of consumer associations of the European network should be based on the principles of safety, quality, availability, sustainable development and information for consumers. The main points of this activity reflected in relations with the European Food Safety Authority (EFSA), and also play a key role in many discussions related to health, nutrition, quality and safety of food products. The main ingredients of the EuroCoop food policy are health and nutrition; local production; new technology.

Most consumer cooperatives work, first of all, as a network of retailers and, of course, depend on EU policies aimed at businesses in the retail sector. Key points of activity of retail enterprises are equal conditions for all types of enterprises; availability of goods and services for consumers; eliminating food supply chain imbalances; the role of private brands.

The fundamental-organizational direction of activity based on the basic features of the functioning of enterprises and organizations of cooperative form of management, which reflected in the policy of cooperative identity and consumer policy. Key emphasis on cooperative identity policy is cooperative law; cooperative social responsibility; membership; consolidation.

The main priorities of the European Consumer Cooperative Network are the rights, aspirations and interests of consumers as direct owners of enterprises and organizations. The key focus of consumer policy is education and consumer information; product safety; consumer rights and collective redress.

As enterprises created by consumers for consumers, the strategic aspirations of consumer cooperatives are based on the "community care" principle, aimed at ensuring economic, social and environmental sustainability. The key emphasis of sustainable development policies is fair trade; viable consumption and production; climate change.

Conclusion. The highest coordinating body of consumer co-operative retailers and the "voice" of the network of cooperative retailers in Europe is EuroCoop, an organization that unites national unions of consumer cooperatives in 19 European countries and Israel [5]. The key to the successful operation of the European Consumer Cooperative Network EuroCoop is the use of the existing unity of the cooperative movement, the realization of the economic and social potential of the system aimed at supporting the functioning of the consumer cooperatives of the European level.

In the coming years, the main activities of EuroCoop related to the implementation of the project of the International Cooperative Alliance "Cooperative Decade of Confident Growth". The project strategy consists of five components and aims at ensuring the further development of the global cooperative network by lobbying the main advantages of a cooperative business model of management: participation: the cooperative business model gives people the opportunity to participate; constancy: the cooperative business model creates economic, social and environmental sustainability; identity: 
the cooperative business model, being identical (determined by the values and principles of cooperation), places the person in the basis of the decisionmaking process; the legal framework: the cooperative business model requires guaranteed favourable legal norms for its growth; capital: a cooperative business model requires cooperative capital with strict membership control.

Interconnectivity of the components of the project forms its integrity and defines the main goals of the activities of international organizations to coordinate the cooperative movement at the present stage: to bring participation in the membership and management to a new level; to develop cooperatives as guarantors of sustainability; to ensure co-operative identity; Ensure a favourable legal framework for cooperative growth; provide reliable cooperative capital, guaranteeing membership control.

All the above shows the formation of decent organizational and legal principles of European co-operative cooperation and the creation of favourable conditions for the functioning and development of cooperative activities in Europe.

It should be noted that today there are all the necessary historical and institutional prerequisites for the development of international economic collaboration of Ukraine's consumer cooperation with this reputable European cooperative institution. Against this background, the prospects for further research are to substantiate directions and develop measures aimed at maximizing the full benefits and potential of collaboration between the national cooperative system and European and world cooperative institutions.

\section{REFERENCES}

1.ICA Activities. www.ica.coop. Retrieved from http://www.ica.coop/activities/ index.html [in English].

2. Sovremennye tendentsyy myrovoho kooperatyvnoho dvyzhenyia [Contemporary trends of the world cooperative movement]. www.sibupk.nsk.s. Retrieved from http://www.sibupk.nsk.su/public/chairs/cooper/TeorCoop/Histiry/g/7.htm\#3 [in Russian].

3. Cooperative Values and Principles for Corporate Social Responsibility (2017). International Day Cooperatives. Retrieved from_http://www.ica.coop [in English].

4. Euro Coop. Statistics. www.eurocoop.org. Retrieved from http://www.eurocoop.org/en/ members/statistics [in English].

5. European Community of Consumer Co-operatives. www.eurocoop.org. Retrieved from http://www.eurocoop.org/en [in English].

6. Borzaga C., Michie J., \& Blasi R. (2017). The Oxford Handbook of Mutual, Cooperative and Co-owned Businesses. Oxford: Oxford University Press [in English].

7. Cocolina C. (2017). The power of Cooperation. Brussels: Cooperatives Europe [in English].

8. Manzhura, O. V. (2018). Development of a cooperative model of a national economy in the context of European integration. Scientific bulletin of Polissia, 1(13), 129-134. Retrieved from http://nbuv.gov.ua/UJRN/nvp_2018_1(1)_21 [in English].

9. Visyn, V. V., Visyna, T. M., \& Kravchuk, P. Ia. (2017). Osnovni tendentsii rozvytku mizhnarodnoho kooperatyvnoho rukhu na suchasnomu etapi [The main tendencies of the development of the international cooperative movement at the present stage]. Naukovyi visnyk UNU - Scientific herald of the University of UNU. (Vol. 15), 1, 54-59 [in Ukrainian].

ISSN 1727-9313. ВІСНИК КНТЕУ. 2020. 
10. The International Co-operative Alliance. www.ica.coop. Retrieved from http://www.ica.coop/en/international-co-operative-alliance [in English].

11. Statistics and Information on European Co-operatives, ICA. www.coop.org. Retrieved from http://www.coop.org/statistics/html [in English].

12. Euro Coop Annual Report (2016). Retrieved from_http://www.eurocoop.coop/news/ 222-Euro-Coop-Annual-Report-2016.html [in English].

The article submitted to editor's office on 12.03.2020.

Гринюк Н. Кооперативна споживча мережа Свропи.

Постановка проблеми. Головна тенденція розвитку сучасного кооперативного руху - активізація міжнародного співробітництва на регіональному й світовому рівнях. В умовах глобалізації економіки та інформаційної револючії економічна дочільність активізації співпраці кооперативних організацій знаходить своє відображення в більш ефективному механізмі ресурсного забезпечення діяльності, модернізації виробництва, впровадженні нових технологій, обміні досвідом і підготовці кадрів тощчо.

Аналіз останніх досліджень $і$ публікацій показав, щуо недостатня увага приділяється дослідженням засад управління і можливостей діяльності регіональних кооперативних співтовариств як засобу розвитку міжнародної економічної діяльності.

Мета статті - дослідження стратегічних напрямів діяльності Свропейського співтовариства споживчих кооперативів $i$ перспектив розвитку мережі в умовах посилення інтеграції і глобалізації.

Матеріали та методи. У процесі дослідження застосовано загальнонаукові та емпіричні прийоми, щзо базуються на системному підході, використано методи узагальнення, порівняння, аналізу і синтезу, формалізащії.

Результати дослідження. Аналіз як світового, так $і$ європейського досвіду діяльності кооперативного сектора економіки доводить важливу роль споживчих кооперативів у розвитку економіки, особливо під час трансформаційних процесів. Саме в частині споживчої кооперачії сучасний міжнародний кооперативний рух характеризують позитивні тенденції: зростання обсягів діяльності; проникнення кооперації в нові сфери людської життєдіяльності; зростання кількості та підвищення ролі багатофункціональних кооперативів та споживчих товариств у кооперативному секторі економіки; підвищення ролі міжнародного співробітництва на регіональному й глобальному рівнях. Охарактеризовано діяльність Європейського співтовариства споживчих кооперативів (ЕигоСоор), щзо стало однією з перших неурядових організацій, визнаних Європейською комісією, щуо представляють та підтримують структуру і функціонування споживчих кооперативів європейського рівня.

Висновки. Нині основні напрямки діяльності ЕитоСоор пов'язані з реалізацією проєкту Міжнародного кооперативного альянсу "Кооперативне десятиріччя впевненого зростання", спрямованого на забезпечення подальшого розвитку світової кооперативної мережі шляхом лобіювання основних переваг кооперативної бізнесмоделі господарювання.

Наявність інституційних передумов для розвитку міжнародного економічного співробітництва споживчої кооперації України з ичєєю авторитетною європейською кооперативною інституцією обумовлює подальші дослідження в напрямку обтрунтування розробки заходів, спрямованих на максимальне використання всіх переваг та потенційних можливостей співпраці національної кооперативної системи з європейськими та світовими кооперативними інституціями.

Ключові слова: кооперація, споживча кооперація, європейська кооперативна споживча мережа, EuroCoop. 